\title{
Effect of the Stage of Development at Harvest on the Texture, Flavor, Quality and Yields of Frozen Green Bananas ${ }^{1}$
}

\author{
F. Sánchez Nieva, M. Mercado, and C. Bueso ${ }^{2}$
}

\section{ABSTRACT}

For processing frozen green bananas of high quality it is recommended that the fruit be harvested at a pulp to peel ratio of about 1.5. In green handpeeled bananas shear press force values decreased linearly with an increase in pulp to peel ratios. Hot water peeling softens the fruit and results in a reverse relationship of pulp to peel ratios and shear press values, shear press values increasing linearly with pulp to peel ratios. The change in shear press values with pulp to peel ratios in thawed and boiled fruit follows this same pattern. The hardening effect of heating on the pulp texture was detected in sensory analysis. Fruit with a pulp to peel ratio ranging from 1.3 to 1.5 was found to be of acceptable texture. Sensory analysis of the frozen product cooked without thawing showed that the appearance, flavor and sample quality ratings increased as the pulp to peel ratio increased. Fruit with higher pulp to peel ratios had less off-flavor than less developed fruit probably due to the higher tannin content of the latter. No change in carbohydrates, moisture and ascorbic acid content was detected in fruit ranging in pulp to peel ratios from .9 to 1.6. The acidity increased and the $\mathrm{pH}$ decreased as pulp to peel ratios increased.

\section{INTRODUCTION}

In studies of procedures for the freezing of green bananas (10), it was observed that the quality of the processed fruit was apparently related to the stage of maturity at harvest. Sánchez Nieva and Mercado (11) showed that the color of the frozen product ranged from a light gray to a deep yellow depending on the stage of development at which the green bananas were harvested. Sánchez Nieva et al. (9) reported that the quality and yields of fried plantain slices prepared from frozen green fruit were affected by the age at which the plantains were harvested. Higher quality products and yields were obtained when mature fruit was processed. Since there is a strong similarity in processing characteristics between plantains and bananas in the green stage, it was suspected that the stage of development at which bananas are harvested would also have a direct effect on the quality and yields of processed products.

Consequently, a study was conducted to determine the effect of the stage of development at harvest on the different quality attributes and

${ }^{1}$ Manuscript submitted to Editorial Board July 9, 1979.

${ }^{2}$ Consultant Chemical Engineer, Research Assistant and Assistant Food Technologist, respectively, Food Technology Laboratory, Agricultural Experiment Station, Mayagüez Campus, Río Piedras, P.R. The staff of the Corozal Substation and Mr. R. Guadalupe, Assistant Horticulturist, Food Technology Laboratory, were in charge of the experimental plot and harvesting of the fruit used in these studies. Mrs. I. Caloni, Assistant Food Technologist, Food Technology Laboratory, conducted the organoleptic tests. 
yield of frozen green bananas and to determine the optimum stage for harvesting the fruit for a frozen product of the highest quality.

\section{MATERIALS AND METHODS}

To provide the fruit for these studies a plot of 200 plants of Montecristo bananas was established at the Corozal Substation. The corms for planting were obtained from the Adjuntas Substation and selected as uniform as possible. Land preparation, cultivation insect and pest control followed the practices recommended for commercial plantations by the Puerto Rico Agricultural Experiment Station (1). During dry weather irrigation was applied as needed.

The date of flowering for each plant was recorded. Harvesting started about 70 days after flowering. Bunches were harvested weekly, ranging in age from 70 to 130 days measured from the date of flowering. The bunches were harvested early in the morning and transported to the laboratory in banana crates to avoid damage. The fruit was stored at 45 F (7.26 C) until processed. With few exceptions the fruit was processed the day after harvest.

The hands were separated from the stems and weighed. Pulp to peel ratios were determined in fruit from the second hand by weighing the pulp and the peel from hand peeled fruit. The fruit for processing was grouped into lots according to their pulp to peel ratios.

The fruit was peeled and frozen as described by Sánchez and Mercado (10) with the following modification: the fruit was sliced after peeling without immersing in water, packed immediately after slicing and frozen. The frozen lots were stored at $-23.33 \mathrm{C}(-10 \mathrm{~F})$ for later studies.

Total acidity, $\mathrm{pH}$, moisture, and ascorbic acid were determined by A.O.A.C. official methods (6); starch was determined by the method of Cater and Neubert (3); and sugars by the method of Moyer and Holgate (5). For texture measurements a Food Technology Corporation shear press $^{3}$ was used as described by Sánchez Nieva and Mercado (10). Shear press measurements were performed in fresh hand-peeled fruit, hot waterpeeled fruit, frozen fruit thawed 2 hours at room temperature and fruit boiled 5 min without previous thawing. Tannins were determined by the method described by Leonard et al. (4) and calculated as tannic acid mg/ $100 \mathrm{~g}$ fresh weight.

For organoleptic tests the contents of one box of frozen slices $(12 \mathrm{oz}$, approx. $320 \mathrm{~g}$ ) were added to two cups ( 0.5 liter) of boiling water with two teaspoons of salt and cooked for $5 \mathrm{~min}$ after the water started to boil again.

\footnotetext{
${ }^{3}$ Trade names in this publication are used only to provide specific information. Mention of a trade name does not constitute a warranty of equipment or materials by the Agricultural Experiment Station of the University of Puerto Rico, nor is this mention a statement of preference over other equipment or materials.
} 
For organoleptic evaluation, attributes such as flavor, off-flavors, appearance and overall sample quality, were rated by a panel of about 10 judges using a 6-point scale. Texture was rated using descriptive terms ranging from soft to hard with normal texture in the middle of the scale, which ranged from 1 for soft to 9 for hard, the normal texture being given a score of 5. Samples were rated singly under normal fluorescent room lighting.

\section{RESULTS AND DISCUSSION}

When green bananas were harvested ranging in pulp to peel ratios from .99 to 1.8 , shear press measurements indicated that as the fruit matures it becomes softer. Correlation analysis showed a highly significant correlation of shear press values and pulp to peel ratios $(r=-0.4524)$. The change in shear press values with pulp to peel ratio is linear; the regression equation explaining this relationship is $Y=570.73-57.08 X$, where $Y$ is

TABLE 1.-Changes in shear press force values with pulp to peel ratio, in green handpeeled, hot water-peeled thawed and boiled fruit

\begin{tabular}{ccccc}
\hline \multirow{2}{*}{$\begin{array}{c}\text { Pulp/peel ratio } \\
\text { interval }\end{array}$} & \multicolumn{4}{c}{ Shear press force } \\
\cline { 2 - 5 } & Green fruit & $\begin{array}{c}\text { Hot water } \\
\text { peeled }\end{array}$ & Thawed & Boiled \\
\hline & $L b$ & $L b$ & $L b$ & $L b$ \\
1.01 & 510.0 & 177.0 & 256.0 & 27.0 \\
1.21 & 495.0 & 198.0 & 203.0 & 40.5 \\
1.26 & 431.2 & 222.0 & 162.0 & 45.75 \\
1.32 & 510.0 & 229.5 & 197.3 & 52.5 \\
1.47 & 465.0 & 204.0 & 226.5 & 46.5 \\
1.55 & 446.0 & 177.0 & 279.0 & 71.25 \\
1.65 & 465.0 & 195.0 & 301.5 & 83.25 \\
\hline
\end{tabular}

shear press force values in $\mathrm{lb}$ and $X$ is the pulp to peel ratio. With respect to the change in shear press values with an increase in pulp to peel ratios, green bananas follow the same pattern that was observed in plantains harvested by Sánchez Nieva et al. (7) at different stages of development.

When the fruit was peeled by immersing in water at $93 \mathrm{C}(200 \mathrm{~F})$ for 30 min, a decrease in shear press values resulted (table 1), indicating that the treatment softened the fruit appreciably. Correlation analysis showed a significant correlation between shear press values and pulp to peel ratios $(r=0.3225)$. However, the change in shear press values with pulp to peel ratios in the peeled fruit showed a pattern different from that observed in the hand-peeled green fruit, shear press values increasing as the pulp to peel ratios increased. Figure 1 indicates the change in shear press values with pulp to peel ratios in the hand-peeled fresh fruit and in the hot water-peeled fruit; the regression equations for each case have been plotted. 
Table 1 shows the changes in texture that took place when the frozen fruit was thawed at room temperature for $2 \mathrm{hr}$ and when cooked without previous thawing by boiling in water for $5 \mathrm{~min}$. Shear press values for the thawed fruit were considerably higher than for the hot water peeled fruit. In the thawed fruit a definite trend is also observed for the shear press values to increase with an increase in pulp to peel ratios.

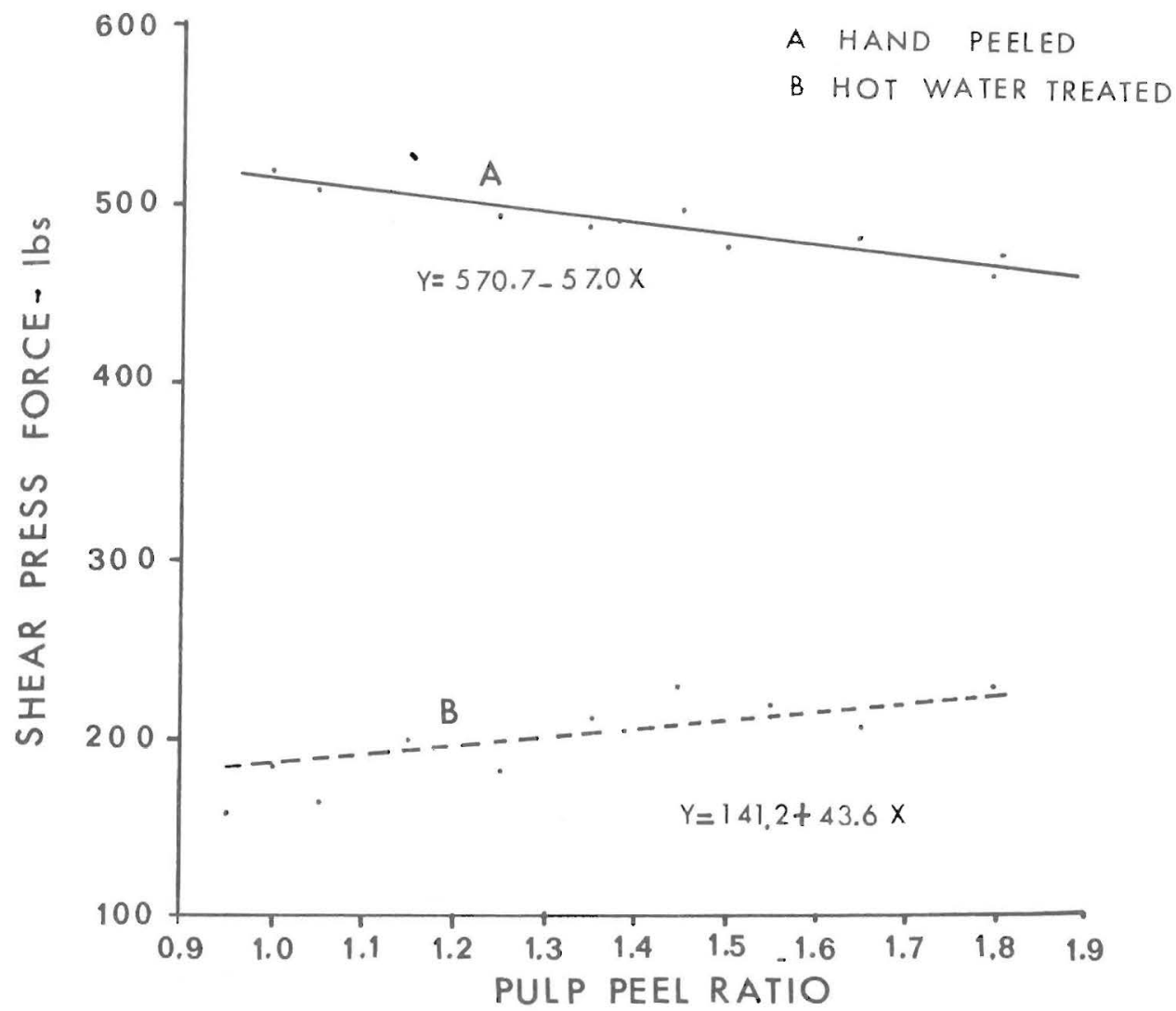

FIG. 1.-Change in texture (shear press force values) with pulp:peel ratios in hand- and hot water-peeled fruit.

When the fruit was boiled it softened considerably, but the change in shear press values with pulp to peel ratios followed the same pattern observed in the hot water-peeled and thawed fruit, increasing in value with an increase in pulp to peel ratio.

Table 2 includes the results of sensory analysis in which the frozen samples boiled $5 \mathrm{~min}$ in water as described under Material and Methods 
were rated for texture, appearance, flavor, off-flavor intensity and overall sample quality. The scores for texture show that tasters could detect the small difference in texture indicated by shear press measurements, finding the samples with a higher pulp to peel ratio harder than those less developed. Samples considered to have a normal texture (score of 5) had a pulp to peel ratio ranging from 1.3 to 1.5 .

The score for appearance increased as pulp to peel ratios increased. The improved appearance of the samples at the higher pulp to peel ratios was found by Sánchez Nieva and Mercado (11) to be due to an increase in the intensity of the yellow color with maturity, which was paralleled by an increase in the carotene content.

Flavor ratings were lower for fruit with pulp to peel ratios below 1.4 than for more mature fruit. Likewise, off-flavor intensity rating indicate the presence of some off-flavors in the less developed fruit and almost none in the more mature samples.

The overall sample quality improved as the pulp to peel ratio increased.

TABLE 2.-Results of sensory analysis of frozen green bananas

\begin{tabular}{lcccccccccc}
\hline \multirow{2}{*}{ Attribute } & \multicolumn{7}{c}{ Rating $^{2}$ based on indicated pulp/peel ratio } \\
\cline { 2 - 11 } & 1.01 & 1.13 & 1.21 & 1.26 & 1.34 & 1.46 & 1.56 & 1.65 & 1.69 \\
\hline Appearance & 1.1 & 3.1 & 2.7 & 2.8 & 2.7 & 3.2 & 4.4 & 3.9 & 4.5 \\
Flavor & 2.6 & 3.1 & 3.0 & 3.2 & 2.7 & 3.5 & 4.1 & 3.5 & 3.8 \\
Off-flavor intensity & 4.6 & 4.7 & 4.5 & 4.5 & 5.0 & 4.8 & 5.0 & 5.0 & 4.9 \\
Texture & 3.0 & 4.9 & 3.1 & 4.2 & 5.0 & 4.9 & 5.1 & 5.4 & 5.4 \\
Sample quality & 1.9 & 3.0 & 3.0 & 3.0 & 2.9 & 3.8 & 4.3 & 3.7 & 3.6 \\
\hline
\end{tabular}

${ }^{1} 1$-poor to 6 -good, in a 6 -point scale.

A product with more attractive appearance, acceptable texture, better flavor and higher overall quality resulted when the bananas were harvested at a pulp to peel ratio approaching 1.5.

From the economic point of view, harvesting at this advanced stage of development will result in higher returns for both the farmer and the processor. Assuming a stand of 800 plants per acre, harvesting at a pulp to peel ratio of 1.2 would yield around $10,371 \mathrm{~kg}$ of fruit (in hands), while harvesting at a pulp to peel ratio of 1.5 will yield $12,836 \mathrm{~kg}$. At the current farm price of about 9.9 cents per $\mathrm{kg}$ this difference in production would represent an additional net income of 244 dollars for the farmer. To the processor, harvesting at a pulp to peel ratio of 1.5 would represent an increase in the yield of about 10\% per $\mathrm{kg}$ of the raw fruit purchased.

Table 3 shows the chemical composition of frozen fruit at different stages of development as indicated by the pulp to peel ratios. In the maturity interval studied, no appreciable change in starch and total sugars was observed. The moisture and ascorbic acid content did not 
follow any pattern of change in these samples. The acidity of the fruit increased as the pulp to peel ratio increased $(r=0.6459)$ with a corresponding decrease in $\mathrm{pH}(r=.5407)$ for $\mathrm{pH}$ calculated as specific acidity.

In previous studies reported by Sánchez Nieva et al. (8), in which green bananas of the Montecristo cultivar were harvested at different stages of development ranging in pulp to peel ratios from 1.06 to 1.74 , the starch content was found to range from 34.5 to $27.7 \%$ fresh pulp weight. In this study, (table 3 ) the starch content of fruit harvested at similar pulp to peel ratios was found to range from 18.6 to $21.4 \%$ fresh pulp weight, a striking difference from previously reported values (8).

Since it is very unlikely that the difference in the starch content of green bananas observed in these two studies is due to difference in fruit composition, and furthermore, since the same analytical procedure (3)

TABLE 3.-Chemical composition of frozen bananas at different pulp:peel ratios

\begin{tabular}{ccccccc}
\hline $\begin{array}{c}\text { Pulp:peel } \\
\text { ratios }\end{array}$ & $\begin{array}{c}\text { Total } \\
\text { sugars }\end{array}$ & Starch & Moisture & $\begin{array}{c}\text { Ascorbic } \\
\text { acid }\end{array}$ & $\mathrm{pH}$ & Acidity \\
\hline & $\%$ & $\%$ & $\%$ & $m g / 100 g$ & & $\%$ \\
0.84 & 0.37 & 19.82 & 73.39 & 5.35 & 5.28 & 0.14 \\
1.03 & 0.28 & 20.45 & 70.28 & 8.08 & 5.27 & 0.15 \\
1.04 & 0.56 & 19.72 & 71.46 & 3.18 & 5.18 & 0.14 \\
1.12 & 0.36 & 18.63 & 72.42 & 7.52 & 5.31 & 0.15 \\
1.18 & 0.29 & 20.19 & 72.92 & 5.82 & 5.20 & 0.13 \\
1.27 & 0.41 & 20.40 & 69.48 & 4.83 & 5.43 & 0.16 \\
1.33 & 0.32 & 20.01 & 74.32 & 5.34 & 5.28 & 0.14 \\
1.36 & 0.46 & 19.72 & 74.63 & 8.71 & 5.19 & 0.14 \\
1.46 & 0.28 & 21.41 & 73.73 & 5.82 & 5.45 & 0.13 \\
1.49 & 0.33 & 21.30 & 70.34 & 0.0 & 5.49 & 0.17 \\
1.51 & 0.28 & 21.13 & 73.75 & 6.28 & 5.29 & 0.17 \\
1.55 & 0.30 & 20.84 & 69.99 & 7.19 & 5.34 & 0.18 \\
1.59 & 0.37 & 21.15 & 70.45 & 5.31 & 5.41 & 0.17 \\
\hline
\end{tabular}

for the starch determination was used, preliminary investigations were conducted to determine the possible causes of this discrepancy.

Examination of the data from both studies revealed that in the 1969 experiments starch was determined in fresh or frozen hand peeled fruit which had received no heat treatment before analysis. In the present studies, the unpeeled green bananas were heated in water at $93 \mathrm{C}(200 \mathrm{~F})$ for $30 \mathrm{~min}$, then peeled and frozen. Because that discrepancy in the results of the starch analysis could have been due to the effect of the heat treatment, green bananas were peeled by hand without any previous treatment, while other bananas from the same hand were treated in hot water as previously indicated. The results of the starch analysis showed that the hand-peeled fruit had a starch content of $34.65 \%$ while the hot water peeled fruit had a starch content of $21.36 \%$. Therefore, the differ- 
ence in the starch content observed in these studies is apparently due to the effect of the hot water treatment, and not to differences in fruit composition or analytical errors. At present we have no explanation for the effect of heat treatment on the starch determination.

The tannin content was found to decrease as the pulp to peel ratio increased:

$\begin{array}{cc}\begin{array}{c}\text { Pulp:peel } \\ \text { ratio }\end{array} & \begin{array}{c}\text { Tanninns } \\ \text { mg/100 g }\end{array} \\ 0.97 & 198.0 \\ 1.0 & 241.4 \\ 1.10 & 296.0 \\ 1.18 & 215.1 \\ 1.32 & 151.1 \\ 1.41 & 125.2 \\ 1.53 & 112.6\end{array}$

The higher tannin content of the samples of low pulp to peel ratio may account for the higher level of off-flavors in these samples, since the presence of tannins in bananas is the cause of the astringent flavor in partially ripened fruit (2).

\section{RESUMEN}

Para obtener guineos verdes congelados de alta calidad, la fruta debe cosecharse en un estado de desarrollo que corresponda a una razón de pulpa a cáscara de 1.5. Cosechar y procesar el guineo verde en este estado de desarrollo redundará en beneficios económicos tanto para el agricultor como para el industrial, pues tanto la producción por cuerda como el rendimiento industrial acrecen al aumentar la razón de pulpa a cáscara, en la fruta.

Cuando se cosechó en distintos estados de desarrollo se observó que en el guineo verde sin tratamiento previo, mondado a mano, los valores de textura medidos en la prensa de la Food Technology Corporation (shear press) disminuyeron al aumentar la razón de pulpa a cáscara. Cuando la fruta se trató con agua a $93^{\circ} \mathrm{C}\left(200^{\circ} \mathrm{F}\right)$ por 30 minutos para inactivar el sistema enzimático y facilitar el mendarlos, la fruta se ablandó, y las medidas de textura indicaron que la fruta con razones de pulpa a cáscara más alta tenían valores de textura más altos que las que tenian una razón de pulpa a cáscara más baja. La relación entre la textura y la razón de pulpa a cáscara en la fruta hervida en agua por 5 minutos fue similar a la observada en la fruta tratada en agua caliente aun cuando ésta se ablandó al cocerse.

Al someterse las muestras a evaluación organoléptica, los catadores apreciaron un aumento en la dureza en relación directa al aumento en la 
razón de pulpa a cáscara. La fruta con una razón de pulpa a cáscara entre 1.3 y 1.5 fue de textura aceptable.

Las muestras con una razón de pulpa a cáscara de alrededor de 1.5 fueron de mejor sabor, apariencia y calidad general que las preparadas de fruta menos desarrollada. En la fruta menos desarroliada los catadores detectaron sabores extraños ligeramente perceptibles, lo que posiblemente se deba a que estas muestras tenían un contenido de taninos más alto que las más desarrolladas. El contenido de taninos disminuyó al aumentar la razón de pulpa a cáscara.

No se encontró variación significativa en el contenido de almidón, azúcares totales, humedad y ácido ascórbico en muestras cuya razón de pulpa a cáscara fluctuó entre .84 a 1.6. En estas muestras al aumentar la razón de pulpa a cáscara aumentó la acidez y disminuyó el pH.

\section{LITERATURE CITED}

1. Annon., 1975. Conjunto tecnológico para la producción de plátanos y guineos, Esta. Exp. Agri., Univ. P.R., Pub. 97.

2. Barnell, H. R. and Barnell, E., 1945. Studies in tropical fruits, XVI, Ann. Bot. Lond. 9, 77-79.

3. Carter, G. H. and Neubert, A. M., 1954. Rapid determination of starch in apples, J. Agri. Food Chem. 2 (21): 1070-72.

4. Leonard, S., Luh, B. S., and Heinreiner, E., 1953. Flavor evaluation of canned cling peaches, Food Technol. 7: 480-5.

5. Moyer, J. C. and Holgate, K. C., 1948. Determination of alcohol insoluble solids and sugar content of vegetables, Anal. Chem. 20 (5): 472-4.

6. Official Methods of Analysis of the Association of Official Agricultural Chemists, 12th ed, Washington, D.C., 1975.

7. Sánchez Nieva, F., Colom Covas, G., Hernández, I., Guadalupe, R., Díaz, N., and C. B. Viñas, 1968. Preharvest changes in the physical and chemical properties of plantains, J. Agri. Univ. P.R. 52 (3): 241-55.

8. -,$-\longrightarrow$, Bueso, $\mathrm{C}$., and Guadalupe, R., 1969. Studies on the production of Montecristo bananas grown on the south coast of P.R., J. Agri. Univ. P.R. $53(4)$ : 284-306.

9. — - Hernández, I., Guadalupe, R., and Bueso, C., 1971. Effect of time of planting on yields and processing characteristics of plantains, J. Agri. Univ. P.R. 55 (4): 394-404.

10. - and Mercado, M., 1978. Effect of peeling method and sulfitation on the shelf life of frozen green bananas, J. Agri. Univ. P.R. 62 (3): 241-8.

11. - and Mercado, M., 1980. Relationship between the stages of development at harvest and the color of frozen green bananas, J. Agri. Univ. P.R. 64 (3):283-293. 